\title{
THE INFLUENCE OF CONTRACT FARMING TOWARD THE FEASIBILITY OF QUAIL CULTIVATION BUSINESS IN SUKABUMI REGENCY
}

\author{
Juliyanti Indri*, Syarief Rizal, Harianto \\ School of Business, Bogor Agricultural University, Indonesia \\ *E-mail: juliyantiindrii@gmail.com
}

\begin{abstract}
The largest quail population of West Java located in Sukabumi, where its many residents do quail cultivation business. In growing its business, the breeders have problems such as scientific knowledge, capital, management, and marketing. One of the solutions is through a partnership with CV Slamet Quail Farm. This study aims to analyse the feasibility of quail cultivation business as well as profitability level of partner breeders and independent breeders in Sukabumi Regency by using investment criteria, and to analyse the sensitivity of quail cultivation business feasibility toward the partner breeders and independent breeders if there is increasing feed price, decreasing selling price of egg, and decreasing amount of egg production due to disease.
\end{abstract}

\section{KEY WORDS}

Investment analysis, sensitivity, partnership, quail cultivation business.

Agribusiness is one of the diverse employment sectors which can absorb massive workforce. Indonesia is basically an agrarian country where most of population work in the agribusiness sector. Currently, livestock is one of the agribusiness sectors which have a positive trend among the people; one of them is quail farms. One type of quail developed in Indonesia is Coturnix japonica which is originated from the Japan. The quail has a very high economic value where the meat, eggs, feathers, and feces can generate income and it is hardly produces any waste. Another advantage of quail cultivation is the price of quail eggs which are always above the production cost (Wuryadi 2014).

Based on data from Directorate General of Animal Husbandry and Animal Health, Ministry of Agriculture (2017), it is noted that the amount of production and consumption of quail eggs has increased annually from 2013 to 2016 . The growth rate of its production in 2015 until 2016 has increased by $6.52 \%$, while consumption of quail eggs increased by $16.4 \%$. This explains that the increase in production is not accompanied with the increase of consumer demand. The condition shows an opportunity for farmers to gain profit in quail egg business development. The quail cultivation business development has been widely done, but still empowered by the UMKM breeders. Based on data from Livestock Department, West Java Province (2014), the largest quail populations in West Java is in Sukabumi District. Most breeders in Sukabumi join as partner farmers in CV Slamet Quail Farm (SQF). The group members of quail cultivation partner spread in 16 subdistricts in Sukabumi.

The contract farming is defined as an agreement between breeders and the company in product supply with a specified period of time and predetermined price (Eaton and Shepherd 2001). It is also one solution to overcome the gap between large entrepreneurs and small entrepreneurs (Hafsah 2003). CV SQF provides training, mentoring, and advisory services to address the gap between the company and partner as well as assist the selling partner farmer's production at a set price. According to Saputra (2009), the business partnership model should involve big business and small business by involving the bank as a lender in a cooperative engagement as outlined in memorandum of understanding (MoU). Until now CV SQF has cooperated with one of the banks in Indonesia to give credit to members of breeder partners so that they have no difficulty in terms of business capital.

Hafsah (2003) suggested that there are several types of partnership patterns which have been widely implemented, namely the plasma core pattern, sub-contract pattern, general trading pattern, density pattern, and franchising. The partnership pattern applied by CV SQF 
with partner breeders is the free plasma core pattern, where there is no written bond between CV SQF and the breeders. A previous research by Suwarto (2003), suggested that quail livestock business is prospective as it has enormous potential resources and large market share. According to Eaton and Shepherd (2001), contract farming can provide countless benefits for the parties involved, especially for farmers/breeders, namely the provision of inputs and production services, credit access, the introduction of appropriate technology, expertise transfer, fixed prices, and access to reliable markets.

Farmers participating in the partnership program will generally have a higher rate of profit than independent farmers (Bolwig et al 2009). Yunus (2009) suggested that independent breeders are more profitable than those who become a member of partnership pattern. Sanjaya et all (2016) argued that based on financial analysis, the quail livestock business in Tebing Tinggi Okura Rumbai Pesisir is feasible to cultivate. Based on these descriptions, some studies need to be conducted to see the relationship between the partnership pattern with the benefits gained by partner breeders. The focus of this research is to analyse the quail cultivation business by considering revenues and expenditures of partner breeders and independent breeders in Sukabumi. Based on the description, the purpose of the study is to measure the level of profit gained in quail cultivation business between partner farmers and independent breeders.

\section{METHODS OF RESEARCH}

The location of this research was in Sukabumi Regency for both partner farmer and independent breeder. The determination of research location was done purposively or intentionally on the basis that Sukabumi is biggest quail egg producer in West Java and have partner breeders group, which CV SQF. The location of partnership implementation is in Sukabumi Regency, while the company is in Cikembar District. The data used in this research comes from primary and secondary data. The primary data generated from direct interviews with respondents in the field. The secondary data obtained from literature studies relevant to the research topic.

Data collection methods used were surveying methods, through direct interviews with the members of partner breeders and independent breeders through the questionnaire, and through direct discussion with breeders of CV SQF. The sampling method for partner breeder was random sampling, in which researchers randomly selected respondents from partner breeding members in the population. The sampling method for independent breeders was snowball sampling where researcher look for one independent breeder and ask the respondent to give information of others residing in Sukabumi. The number of quail cultivation breeders involved as respondents in this study is 20 , consisting of 10 partner breeders and 10 independent breeders. The data analysis method used in this research is investment analysis to see the profit obtained by partner breeders and independent breeders.

\section{CRITERIA OF FEASIBILITY}

The assessment of investment analysis in this study was conducted by four criteria, namely: NPV, IRR, Net B/C, and PBP. By using this assessment, the benefits gained by partner breeders and independent breeders in Sukabumi District can be compared. Sensitivity analysis was also used to know the sensitivity of quail cultivation business to feed price change, production quantity, and selling price so that influences investment analysis assessment.

NPV or Net Present Value is the current value of a project's investment income flow by looking at the present value of a project's benefits with the present value of a project's investment cost (Gittingger 2008). Projects are considered feasible and profitable to be implemented if the value of NPV is positive. If NPV is negative, the project is considered not feasible to implement. In a negative NPV condition, it is better to run another better project than investing capital in the business.

The IRR or internal rate of return is the maximum interest rate can be paid to run the project, where the project can be run with greater internal rate return than the limit level which is 
generally the opportunity cost of capital (Gittinger 2008). According to Sunyoto (20014), IRR is used to measure the benefit of own capital to generate profits. If the IRR value is greater than bank interest, then the project is eligible for a credit. If the IRR value is less than bank interest, then the project is not eligible for a credit.

Net $B / C$ or benefit and cost ratio are obtained when the present value of benefit flows is divided by the present value of cost flow (Gittinger 2008). If the Net B/C is less than one, then the present value of cost will be greater than the present value of the benefit, and the first expense plus the return for investment in the project will not be able to return. The formal criteria used for Net $B / C$ size selection of project benefits is by selecting all free projects with Net $B / C$ value of one or more.

The PBP or pay back period is a method of investment or valuation calculation techniques on the lifetime of a project or business investment (Sunyoto 2014). PBP or repayment period is the return period of the total capital invested on a project, which is set from the beginning to the net value of the additional production so that it reaches the total amount of invested capital (Gittinger 2008). As long as the project can recover the investment cost before the project ends, the project can still be implemented. But if until the time the project ends it cannot return the investment cost used, then the project should not be implemented.

Sensitivity analysis is an analysis which considers the effect of the risk and uncertainty in the project analysis. It is done by switching value which is done by changing important variables, each can be separated or in combination, with a certain percentage which is already known or predicted. Then, an assessment is conducted to find out how the change sensitivity of those variables have an effect on investment analysis, namely NPV, IRR, and Net B/C value. In agriculture, the project varies due to four significant issues: price, implementation delay, cost increase, and yields. The changing factors will certainly affect the feasibility of a business or project activity. Therefore, it is necessary to analyse and identify the possible conditions from the appropriate information related to the business (Gittinger 2008).

\section{RESULTS AND DISCUSSION}

The background of partnership pattern formation on CV SQF originated from the desire of company's owner to develop quail cultivation business. The needs of clarity on price guarantees and understanding of good processing management make breeders interested in making partnerships. Thus, there is a mutual relationship between quail breeders with CV SQF. The partnership pattern applied by CV SQF with partners is free plasma core pattern, where there is no written bond between CV SQF and breeders.

CV SQF acts as a core company who plays a role in meeting the needs of seeds, feed, vaccines, vitamins, cage equipment, coaching services, and price guarantees. Partner breeders act as plasma obliged to sell their harvest to the company. The partnership undertaken by CV SQF is the free plasma core, where the partner breeders are allowed to sell the production and purchase livestock production facilities from outside other than CV SQF. In addition, breeders are allowed to sell egg production to other companies or parties, but the selling price of eggs should not be below the selling price of CV SQF. Partner breeders have an obligation to attend quail cultivation training and follow SOP which is set by the company.

Breeders who want to apply as partners of CV SQF must meet several requirements, namely following the compulsory training for 7 days and having owned/rent land for cages. Training is done so that farmers can apply the same quail cultivation system with CV SQF and follow the SOP. The quail cultivation training is free of charge. The partners who are new in raising quail cultivation is given special guidance and monitoring in process. The advantages obtained by partner breeders compared with independent breeders can be seen in Table 1 .

The quail cultivation business in this research is divided into two patterns namely, partnership pattern and independent pattern. The former is a business pattern conducted by breeders and CV SQF according to the agreement of both parties. The independent pattern is conducted by breeders without agreement or cooperation with any party. The production focus of quail cultivation business is to generate consumed quail egg and meat. 
Table 1 - Benefits Obtained by Partner Breeders Compared with Independent Breeders

\begin{tabular}{clcc}
\hline No & \multicolumn{1}{c}{ Benefits } & Partnership Breeders & $\begin{array}{c}\text { Independent } \\
\text { Breeders }\end{array}$ \\
\hline 1. & Getting theory and practice guidance on quail cultivation & $\mathrm{X}$ \\
\hline 2. & Quail cultivation assistance in the field & $\checkmark$ & $\mathrm{X}$ \\
\hline 3. & Supervision facility on livestock's health & $\checkmark$ & $\mathrm{X}$ \\
\hline 4. & Selling price clarity for products & $\checkmark$ & $\mathrm{X}$ \\
\hline 5. & Getting capital for quail cultivation activities & $\checkmark$ & $\mathrm{X}$ \\
\hline 6. & 24-hour Consultation & $\checkmark$ & $\mathrm{X}$ \\
\hline 7. & Feed availability guarantee & $\checkmark$ & $\checkmark$ \\
\hline
\end{tabular}

Note: $\checkmark(Y e s) ; X(N o) ; X^{*}$ (Several independent breeders get capital in the form of loans from banks or investors with profit sharing system).

Based on partnership pattern research, breeders invested 5.400 quail aged 40 days with a portion of 5000 laying quails and 400 broiler quails. In the independent pattern, the breeders invested 5.402 quails aged 40 days with a portion of 5000 laying quail and 402 broiler quail. Female quails from breeders' own nursery are not sold and used as the replacement for rejected or dead laying quail. Laying and broiler quails are productive for 18 months or equivalent to 548 days. Based on the prevailed SOP, the quail nursery on partnership pattern requires 4 female quail and 1 male quail, whereas the independent pattern requires 5 female quail and 1 male quail.

A land area of $100 \mathrm{~m} 2$ can accommodate 5,000-6,000 quails. The area is used for starter cage, grower cage, layer cage, hatchery room, and warehouse. Starter cage is used for quail aged 0-21 days. A starter cage unit can accommodate 240 quails consisting of 5 floors whose size are $P=100 \mathrm{~cm}, L=60 \mathrm{~cm}, T=40 \mathrm{~cm}$ for each level. One grower and layer cage can accommodate 200 quails consisting of 5 floors with the size of $P=100 \mathrm{~cm}, L=60 \mathrm{~cm}, T=30 \mathrm{~cm}$ for each level. Each starter, grower, and layer cage can be used for 3 years. The buildings used for quail cultivation are made of iron and plywood as well as tarps to close the cage.

The average consumption of quail feed in this study is 3.9 grams/quail/day for the age 0-7 days. For the age of 8-14 days, the average need is 7 grams/quail/day. The quail aged 15-21 days require approximately 9.4 grams/quail/day, while the 22-30 days requires about 11.3 grams/quail/day. As for the quail aged 31 days-reject an average requires 22.5 grams/quail /day. According to Wheindrata (2013), the average consumption of quails aged 0-7 days is 3.6 grams/quail/day, $8-14$ days is $6.8 \mathrm{gram} / q u a i l / d a y$, age $15-21$ days is $8,9 \mathrm{grams} /$ quail /day, age $22-30$ days is 10.8 grams/ quail/day, and age 31 day-reject is $14-18$ grams/quail/day.

The vaccine for quail is given since the age of 4 days. The next vaccine schedule is at the age of 27 days, 60 days, and 2 months after the last vaccine schedule. The vitamin is given since the age of 1-14 days for the consecutive days with different doses and types of vitamins. Furthermore, at the age of 14 days-reject, the vitamin is given twice a week. Egg-tray is used to pack eggs to avoid damage, with the capacity of 100 items/tray. Disinfectant spraying is done twice a week, after using hatching machine and before the quails are moved from the starter to grower cage and from the grower to layer cage.

The breeders' income flow is obtained from the selling of consumed quail eggs, quail seed eggs, male quail, rejected quail, and quail poop. The average productivity level of laying quail and breeding quail is $80 \%$ per day. 5.000 laying quails produce 4,000 consumed eggs/day. 320 female breeder quails produce 256 seed eggs/day seed. The seed eggs which are not hatched are sold to other quail farmers. The male quail is sold as broiler quails at the age of 30 days. In the first year, the income from the male quail selling starts from the 3rd month. The average rejected quail reaches $50 \%$ of the population. The poop generated from 5,400 quails is approximately 1,5 sacks/day. The selling price of quail cultivation products on partnership pattern and independent pattern can be seen in Table 2.

Table 2 shows the selling prices differences between partnership patterns and independent patterns. The revenue of partnership pattern on the first year was Rp544.193.200 and on the second to seventh year was Rp555.921.200. The income of independent pattern in the first year was Rp 504.657.592 and in the second to seventh was Rp519.673.592. Based on the data processing from respondents of both pattern, it can be seen that partner breeders get 
more income than the independent one, this is due to different selling prices between the two quail cultivation business patterns.

Table 2 - The Selling Price of Quail Cultivation Products on Partnership and Independent

\begin{tabular}{lll}
\hline Products & Partnership Pattern & Independent Pattern \\
\hline Consumed quail egg & Rp 298/item & Rp 279/item \\
\hline Seed egg & Rp 1,130/item & $\operatorname{Rp~970/item~}$ \\
\hline Male-quail meat & Rp 4,500/tail & $\operatorname{Rp~7,000/quail~}$ \\
\hline Rejected-quail meat & Rp 4,000/tail & $\operatorname{Rp~5,200/~quail~}$ \\
\hline Quail poop & Rp 10,000/sack & $\operatorname{Rp~6,200/sack~}$ \\
\hline
\end{tabular}

The expenditure flow on quail cultivation business consists of investment cost and operational cost. The investment cost is the cost incurred by the breeders in the first year. Operational costs consist of variable costs and fixed costs. Investment costs consist of buildings, aviaries, hatching machines, vehicles, quail, and other equipment. The total investment cost to be spent in the first year by the partner breeders was Rp258.140.600, while the investment cost required by the independent breeders is Rp240.510.500.

Variable costs incurred by breeders consist of feed, vitamins, vaccines, egg-trays, and disinfectants. The average feed price for quail aged 0-30 days in partnership pattern is Rp6.682/ $\mathrm{kg}$, while the average feed price for quail aged 31 days-reject is $R p 5.754 / \mathrm{kg}$. The average feed price for quail aged 0-30 days in the independent pattern is Rp6.076/ $\mathrm{kg}$, while the feed price for 31 day-reject quail is an average of Rp5.876/kg. The total variable cost must be paid by the partner breeders is Rp305.640.538/year, while the independent breeder is Rp309.682.860/year.

The fixed costs consist of employee and owner salary, maintenance, electricity, land rent, telephone, transportation, and unexpected costs. Maintenance costs are budgeted at $1 \%$ which covers the vehicle, aviary/cage, and machine maintenance. The unexpected costs are budgeted at $2 \%$ of the total fixed costs. The total fixed costs to be incurred by partner breeders amounting to Rp120.582.000/year, while for the independent breeder is Rp118.100.000/year.

Investment analysis aims to determine the feasibility of quail cultivation business on breeders in Sukabumi. The investments analysis conducted on partnerships pattern and independent patterns using the principle of the current value of money is not equal to the future value of money. Investment analysis is also conducted to see what kind of quail cultivation business pattern is more profitable for breeders. The investment analysis in this study uses four criteria, namely NPV, IRR, Net B/C, and PBP. The interest rate used as a discount factor (DF) is $5 \%$ which follows the average bank interest rate in 2017 . The results of the investment analysis on the partnership pattern and independent pattern can be seen in Table 3.

Table 3 - The Financial Analysis of Quail Cultivation Partnership Pattern

\begin{tabular}{lll}
\hline \multicolumn{1}{c}{ Assessment Criteria } & \multicolumn{1}{c}{ Result } \\
\cline { 2 - 3 } & Partnership Pattern & Independent Pattern \\
\hline Net Present Value (rupiah) & Rp 437.435.103 & Rp 252.383.291 \\
\hline Internal Rate Return (percent) & $48 \%$ & $34 \%$ \\
\hline Net Benefit and Cost Ratio & 2,708 & 2,058 \\
\hline Payback Period (year) & 2,58 & 3,64 \\
\hline
\end{tabular}

NPV is the difference between the cost of revenue and expenses paid by breeders with DF of $5 \%$. The NPV value obtained in the partnership pattern is Rp 437.435 .103 , while in the independent pattern is Rp 252.383.291. The NPV value in both patterns is positive, indicating that quail cultivation business on the partnership pattern and the independent pattern is feasible to be developed. IRR is the calculation of investment cost by calculating the interest rate of investment present value and Net Present Value in the future. The IRR value obtained on the partnership pattern is 48 percent, while in the independent pattern is 34 percent. IRR value is greater than the applicable discount rate of 5 percent. IRR> 5 percent indicates that quail cultivation business in both patterns is feasible to be implemented with an internal rate of return on partnership pattern and independent pattern are 48 percent and 34 percent respectively. 
Net $B / C$ is a comparison between positive Net Benefit value and negative Net Benefit value which has been factor-discounted of $5 \%$. Net $B / C$ value obtained in the partnership pattern is 2.708 which means that every Rp 1 capital issued by partner breeders will generate $\mathrm{Rp} 2.708$ profit. The net value of $\mathrm{B} / \mathrm{C}$ in the independent pattern is 2.058 which means that every Rp 1 capital issued by independent breeders will generate Rp 2.058 profit. Net B/C value which is greater than one indicates that quail cultivation business in both patterns is feasible to be developed. The period required for the return of all investment costs in partnership pattern and independent pattern are 2.58 years or equivalent to 2 years 6 months 29 days and 3.64 years or equivalent to 3 years 7 months 21 days respectively.

Sensitivity analysis was used to find out the maximum change in variable cost, selling price, and amount of production which can be tolerated so that quail cultivation business is considered as feasible. The determination of the switching value is obtained from the test results to produce the values of near-zero of NPV, near-discount rate of IRR, Net B/C equal to 1 , and PBP which approach the project period. The result of switching value on partnership pattern and independent pattern can be seen in Table 4.

Table 4 - The Result of Switching Value on Partnership Pattern and Independent Pattern

\begin{tabular}{lll}
\hline Changes & Partnership Pattern (\%) & Independent Pattern (\%) \\
\hline feed prices increase & 29,38 & 16,66 \\
\hline selling price decrease & 19,13 & 11,76 \\
\hline Production decrease & 19,13 & 11,76 \\
\hline
\end{tabular}

Based on the results of sensitivity analysis by using switching value presented in Table 4, the maximum limit of change toward feed-price increase, selling-price decrease of quail egg consumption, and quantity decrease of quail eggs consumption are 29,385469 percent, 19,126079 percent, and 19,126080 percent respectively. If the change exceeds that limit, then quail cultivation business on partnership pattern will be unfavourable for partner breeders. The maximum limit of change toward feed price increase, selling price decrease of quail egg consumption, and quantity decrease of quail eggs consumption are 16,662,877 percent, 11,766656 percent, and 11,766656 percent respectively. If the change exceeds that limit, then quail cultivation business on the independent pattern will be unfavourable for partner breeders.

Based on the comparison of the maximum limit of changes, it can be seen that the feed prices increase have a smaller effect compared with selling-price decrease and production decrease in partner breeders and independent breeders. The result of switching value analysis to the pattern show that quail cultivation business is more sensitive to selling price decrease, and amount of egg production compared with feed price change. It can be seen from the significant percentage of change which can change the investment analysis value of quail cultivation business, both on the partnership and independent patterns. The maximum limit on partnership pattern has a greater value than the maximum limit on the independent pattern. This is due to the benefits obtained by partner breeders are greater than independent breeders.

\section{CONCLUSION AND SUGGESTIONS}

The investment analysis calculation result of NPV value obtained in the partnership pattern is $R p$ 437.435.103, while in the independent pattern is $R p$ 252.383.291. The IRR value obtained on quail cultivation partnership pattern is 48 percent, while the independent pattern is 34 percent. Net $\mathrm{B} / \mathrm{C}$ value obtained in the partnership pattern is 2.708 which means that every Rp 1 capital issued by partner breeders will get a profit of Rp 2.708. The net value of B/C in the independent pattern is 2.058 which mean that every Rp 1 capital issued by independent farmers will get a profit of Rp 2.058.

Based on the investment analysis calculation, the level of profit gained in quail cultivation business on the partnership pattern is more profitable than the independent pattern. This is due to the price received by the partner breeders is greater than independent breeders'. The threeinvestment analysis shows the result of quail cultivation business in Sukabumi is feasible to be cultivated, both by partnership pattern and independent pattern, with PBP of partnership pattern 
and independent pattern of 2.58 years or equivalent with 2 years 6 months 29 days and 3.64 years or equivalent to 3 years 7 months 21 days respectively.

The partnership pattern in quail cultivation business offered by CV SQF can provide value- added for partner breeders so that they can minimize losses and gain bigger profit. Based on sensitivity analysis by using switching value on the partnership pattern and independent pattern, it can be concluded that quail cultivation business is more sensitive to selling price changes and the amount of egg production compared with feed prices changes. It is necessary to have an explicit written contractual agreement about the rights and obligations between CV SQF and partner breeders. The purpose is to give mutually advantages for both parties and high commitment in running a partnership in quail cultivation business.

\section{REFERENCES}

1. Bolwig S, Gibbon P, Jones, S. 2009. The economics of smallholder organic contract farming in tropical africa. Jurnal Elsevier World Development. 37(6): 1094-1104.

2. Direktorat Jenderal Peternakan dan Kesehatan Hewan Kementrian Pertanian. 2017. Statistika peternakan dan kesehatan hewan. (ID): Ditjen PKH.

3. Dinas Peternakan Provinsi Jawa Barat. 2017. Statistik peternakan. (ID): Disnak Jabar.

4. Eaton C, Shepherd AW. 2001. Contract Farming Partnership for Growth. Food and Agriculture Organization of the United Nation. FAO Agricultural Services Buletin 145.

5. Gittinger JP. 2008. Analisa Ekonomi Proyek-Proyek Pertanian. Jakarta (ID): UI Press.

6. Hafsah MJ. 2003. Kemitraan usaha : Konsepsi dan Strategi. Jakarta (ID): Pustaka Sinar Harapan.

7. Ibrahim Y. 2009. Study Kelayakan Bisnis. Jakarta (ID): Rineka Cipta.

8. Sanjaya B, Amalia, Yasid H. 2016. Analisis kelayakan usaha burung puyuh petelur (coturnix coturnix japonica) di Kelurahan Tebing Tinggi Okura Kecamatan Rumbai Pesisir Kota Pekanbaru. Jurnal Ilmiah Pertanian. 13(1): 47-58.

9. Saputra H. 2009. Strategi pengembangan ternak sapi potong berwawasan agribisnis di Provinsi Aceh [tesis]. Bogor (ID): Institut Pertanian Bogor.

10. Sunyoto D. 2014. Studi Kelayakan Bisnis: Bagaimana Menakar Layak atau Tidaknya Suatu Bisnis Dijalankan. Yogyakarta (ID): CAPS.

11. Suwarto I. 2003. Analisis usaha ternak burung puyuh studi kasus di Bekasi [tesis]. Bogor (ID): Institut Pertanian Bogor.

12. Yunus R. 2009. Analisis efisiensi produksi usaha peternakan ayam ras pedaging pola kemitraan dan mandiri di Kota Palu Provinsi Sulawesi Tengah [Tesis]. Semarang (ID): Universitas Diponegoro.

13. Wheindrata HS. 2014. Panduan Lengkap Beternak Burung Puyuh Petelur. Yogyakarta (ID): Lily Publisher.

14. Wuryadi S. 2014. Beternak dan Berbisnis Puyuh 3,5 Bulan Balik Modal. Jakarta (ID): AgroMedia Pustaka. 